PF 2019 (LXXIV): 69-80

\title{
ТЕТЯНА ЯСТРЕМСЬКА
}

Інститут українознавства ім. І. Крип'якевича

Національної академії наук України

вул. Козельницька 4

Львів 79026

tel. +380506479541

e-mail: tetyana.yastremska@gmail.com

\section{ЛОКАТИВНІ ПРИСЛІВНИКИ В ГОВІРКАХ УКРАЇНСЬКОЇ МОВИ: ЛЕКСИКОГРАФІЧНЕ МОДЕЛЮВАННЯ}

КЛЮчОВІ СЛОВА: дериват, семантична структура, мотивація, локативні прислівники, говори української мови.

SŁOWA KLUCZOWE: derywat, struktura semantyczna, motywacja, przysłówki miejsca/ lokatywne, dialekty języka ukraińskiego.

KEYWORDS: derivative, derivative cluster, semantic structure, motivation, locative adverbs, dialects of the Ukrainian language.

\section{LOCAL ADVERBS IN THE DIALECTS OF THE UKRAINIAN LANGUAGE: A LEXICOGRAPHIC MODELING}

ABSTRACT: The article proposes an analysis of locative adverbs; it represents the semantic opposition „top" - „bottom” and fragments of derivative clusters of the base words of the opposition верx, гора („top”) and низ, діл, спід („bottom”) (вверху, вверику, ввершечку, вгорі, вдолі, вдолині, внизу, всподу, всподі).

The purpose of the research is to analyze the peculiarities of the structure and semantics of locative adverbs, form a generalized semantic structure of derivatives according to the semantic subcomplexes of the base words, identify semantically and structurally correlated derivatives, and offer a sample lexicographic modelling of derivatives. More than 2,000 micro-contexts of the function of the adverbs in dialects of Ukrainian language (above all, the southwestern dialect) were analyzed.

The sources were dialect dictionaries, card indices and texts, regional linguistic atlases, ethnographic and dialectal materials starting from $19^{\text {th }}$ c. (Yakiv Holovatsjkyj, Volodymyr Shukhevych, Volodymyr Hnatiuk, Antin Onyshchyk, Ivan Verchratsjkyj, Ivan Franko, et al.). 
In the article, I proposed a new perspective on the analysis of the derivative system in the format of an epidigmatic dialect dictionary which contains information on wordbuilding derivativeness, motivation, and semantics of derivatives.

Однією з найбільш важливих та актуальних проблем дослідження діалектних явищ є проблема словотворення, розв'язання якої передбачає не тільки формування словотвірних гнізд (далі - СГ), з'ясування способів та напрямків деривації, а також лексикографічне моделювання дериватів, укладання словника, який відображатиме комплексний підхід до представлення діалектних явищ - аналіз мотивації, деривації та семантики дериватів.

Об'єктом мого зацікавлення є деривати, які входять у межі базової просторової опозиції «верх - низ», слугують для опису орієнтації об’єкта у просторі, для просторової кваліфікації частини об’єкта, а також формують систему координат мовної картини світу.

У статті пропоную аналіз фрагмента системи дериватів - прислівників, утворених від базових слів верх, гора («верх») і низ, діл, спід («низ»), які посідають провідне місце у формуванні картини простору. Це передбачає виконання низки завдань, а саме: укласти корпус прислівників на матеріалі говорів української мови (передусім південно-західного наріччя); проаналізувати особливості їх семантичної структури, сформувати узагальнену семантичну структуру дериватів відповідно до семантичних субкомплексів (далі - СК) базових слів, виявити семантично і структурно співвідносні деривати, запропонувати зразок лексикографічного моделювання дериватів, а також окреслити низку проблем, пов'язаних із контекстуальним дослідженням діалектного прислівника, із його граматикою, а власне окресленням частиномовної належності, як передумовою коректного визначення семантики.

Джерельною базою слугували записи говіркового мовлення української мови, діалектні словники та картотеки, діалектні тексти, регіональні лінгвістичні атласи, етнографічні й діалектні матеріали від XIX ст. (Яків Головацький, Володимир Шухевич, Володимир Гнатюк, Антін Онищук, Іван Верхратський, Іван Франко, Володимир Кобільник, Марко Грушевський, Іван Панькевич) і дотепер та ін.

\section{1. Корпус локативних прислівників}

Прислівники на зразок вверх, зверха, догори, підгору, вділ, здолини, віднизу, зісподy, позаспід тощо в науковій літературі закріпили за собою назву просторових, локативних, прислівників місця та напряму, які належать 
до лексико-граматичного розряду обставинних прислівників (Грищенко 1997: 452).

Аналізовані прислівники утворені в результаті адвербіалізації форм непрямих відмінків іменників (Gen, Acc, Abl, Loc) з прийменниками (в / y, від / од, д / до, з / із / зі, на, під, по, попід, през) (Німчук 1978: 355-356), а також зі складеними прийменниками, утвореними на діалектному грунті: 3+nid, no+3a. Засвідчено також діалектні деривати, утворені за допомогою префіксації від прислівників повер $x \rightarrow$ зповерx, напо́верx, звер $x \rightarrow$ назверx (чи навер $\rightarrow$ назверх?).

На підставі аналізу понад 2100 мікроконтекстів виявлено 138 прислівників, 21 з яких вживаються у функції прийменників і $2 €$ тільки прийменниками.

Системний аналіз корпусу прислівників, утворених від базових слів опозиції «верх - низ», передбачає дослідження прислівникових дериватів, утворених за різними моделями, а також їх лексикографічне опрацювання.

\section{2. Семантична структура прислівників}

Діалектні словники, фіксуючи просторові прислівники статичної локалізації, наводять переважно «спрощену» семантику, яка за відсутності мовної ілюстрації майже не несе корисної інформації, адже, як виявив аналіз «живих» контекстів, семантика просторових прислівників не може обмежуватися значенням 'угорі' чи 'унизу'. Проте важливе значення має фіксація прислівників у діалектних словниках та вияви фонетичних варіантів; наприклад: в верху 'в горі, на горі' (Мосора 12); в долі 'в долині' (Кміт 23); увер( $)$ xý 'нагорі, угорі', усподý 'унизу' (ГГ 190, 193); уверьху́ 'угорі', всподу́ (yсnодý) 'унизу' (Негрич 45, 172, 173); вверьху́ 'вгорі', вдолинні 'внизу, відносно нижче', всподý 'на дні' (СГРЯ 145, 156, 318), вверху 'на горі', 'у верхній течії річки', вгори́ 'вгорі', уггори́ 'високо', вдолі 'внизу', всподу́ 'внизу' (Он. I 87, 88, 150, 184); угорі, вгорі 'угорі, вгорі; високо в повітрі', вни́зу 'внизу, в нижній частині' (Пиртей 396, 53); удолинні ‘унизу, знизу' (БГС 561); ўдо (БГТ 48); вдолі (ўдол’', удол’') 'внизу' (Матіїв 54, 473) та ін.

Семантичний аналіз дав змогу виявити, що семантика базових слів СГ і дериватів накладається, деривати репрезентують усі семантичні СК, виокремлені в межах семантичних структур базових слів, значення яких часто слугують основою для творення значень дериватів. На підставі аналізу діалектних матеріалів змодельовано узагальнену семантичну структуру прислівників, яка охоплює понад сто компонентів у межах 4 «семантичних субкомплексів із своїм внутрішнім підпорядкуванням похідних значень» 
(Гриценко 1990: 154), об’єднані навколо «центрів-домінант» (Гриценко 1990: 175; Гриценко 1984: 89), перші три з яких вказують передусім на простір, а четвертий - на спосіб дії: I - 'верхня / нижня частина (об'єкта)'; II - 'верхній / нижній край, межа'; III - 'поверхня ('верхній шар' та 'зовнішній бік')'; IV - 'сидячи на коні; верхи'.

Найбільш семантично розгалуженим $є$ I СК 'ве рхня / н ижня час ти на о б' $є$ кта', елементи якого об'єднано за диференційною ознакою 'розташований угорі', а саме: 'у верхній / нижній частині рослини (будівлі, копиці, пристосування (пристрої, прилади, знаряддя), посудини, тіла, одягу)', 'на вершині / у підніжжі гори', 'у верхів'ї / пониззі річки'; 'у верхньому / нижньому кінці села', 'високо в небі / нижче від поверхні землі, під землею', 'вище / нижче щодо іншого об'єкта', а також охоплює значення, що вказують на напрямок: 'знизу угору / зверху вниз'. Зазначу, що точка відліку, орієнтир (лінія / точка), яка розділяє об'єкт на дві частини верхню і нижню - $є$ досить умовною (гора - вершина і підніжжя, дерево верховіття і нижня частина, тіло - верхня (до пояса) і нижня (від пояса) частини, верхня і нижня частина об'єкта, пристосування, посудини та ін.), що часто залежить і від місця перебування мовця. Для формування семантики важливо виокремити просторові параметри, які усвідомлює мовець; «не загубити» його у формуванні семантики. За словами Юрія Апресяна, «фігура мовця організовує семантичний простір тексту, (...) є тим орієнтиром, щодо якого в акті комунікації починається відлік часу і простору» (Апресян 1997: 274). Це, зокрема, підтверджують приклади: Йак то у нас

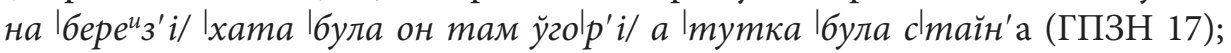
Угор”̈ на поли́ще стойа́у бан' ечо́к (КСГГ); Я тогди був на грусьиі, удолині пес дитину вкусив (БГС 561); вони містять вказівку на додаткову локалізацію на те, що мовець стоїть десь внизу, нижче щодо іншого об'єкта.

Просторова семантика прислівників може трансформуватися у семантику способу дії, наприклад: 'піднявши угору / опустивши вниз' (го́pi, догори́ / до́лом), 'повернувши вгору / униз' (ўверх, уцго́ру, го́р’i, догори́, наве́рx / ўдо-

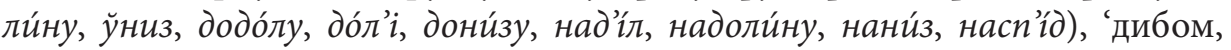
стійма, на задні ноги (про коня)' (ўго́рy, го́р’i, догори́) та ін.

Значення II СК об'єднано навколо семантичної домінанти 'в е р х н і й / нижній край, верхня / нижня межа', зокрема виокремлено семантичні компоненти, які вказують на місце, напрям: 'вище, ніж потрібно; надто високо; зависоко' (горо́ю), 'із верхнього краю; на самому верху' / 'на самому низу; на дні' (зве́рха (u,y), згори́, наве́рха(y), нагор’і / ўспо́d’i(y), надоли́н'i, наспо́d'i), 'до верхнього краю, до верхньої межі / до нижнього краю, до нижньої межі' (дове́рха(y), догори́ / досподá); на кількість: 'через край об'єкта' (зве́рху, пове́р $x(u)$ ), 'понад норму, міру, забагато, більше, ніж 
потрібно' (верхо́м, зве́рх $(u)$, напо́верx, пове́рх $(a, u))$ та ін. Прислівники у деяких прикладах орієнтують не тільки на географічний простір, а й на соціальний - 'попереду, на висоті, у вигідному становищі / позаду, у гіршому становищі' (наве́рс'i, наве́рха / ўсnód’i), 'у панівному становищі / у пригнобленому становищі' (ве́рха, верха́ми, ве́рхом, зве́рха (y), наве́рхи(y) / доли́ною, спо́дом) тощо.

Третій СК формують значення, що вказують на п о в е р х н ю - 'верхній шар' та ‘зовнішній бік', зокрема: ‘по поверхні горизонтального об’єкта (вода, земля тощо) / під поверхнею - з нижнього боку об'єкта (пристосування, посудина, предмет)' (ве́рхом, го́р’i, зверх (a, u, y), згори́, пове́рx $(a, u)$ - до́лу, non'idcn'íd), 'із зовнішнього, лицевого боку; іззовні' / 'із внутрішнього, зворотного боку; із вивороту' (ц̌го́рy, горо́йy, зве́рхи $(y)$, наве́рх $(y)$, пове́рхи ўдоли́ну, ўнизу́, до́лом, з’iсnо́dy, зни́зу).

Значення, пов'язані із краєм, межею та із поверхнею, здебільшого «накладаються», тому складно визначити СК, наприклад:

- 'на самий верх' (II CK) ↔ 'уверх на поверхню водойми (рідини), землі' (III СК) <підтягувати, вихоплюватися, спливати, виходити >: Набрав $\ddot{i}<$ глину> у жменю, та віхопив си у гору. Але заки віринув, вода усу глину вімулила з єго руки (Шух. V 1), То

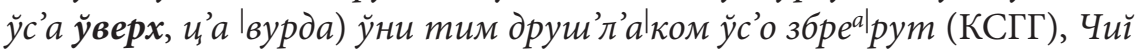
май ско́ро п’íde дгóp' $\boldsymbol{i}$ <про пироги, які варяться> (УЗГТ 133), Як язьи легла нижива, тогди вода из зимлі люгла; из усіх жиліуу вода вілюгла на верх и розилєла сї по иалїм сьвікі́ (ГС 153); Тота гадина далеко у земли, не віходит на верх (ГС 172);

- 'на самий низ, на дно' (II CK) ↔ 'униз на поверхню землі, водойми; на дно, на землю' (III СК) <iти, класти>: Коло нашого ставу є вікнина ['трясовина'], місце таке, шо якби став, так би і пішов удоли́ну (БГС 56), Кла́ли насп'id маргари́ну, на́в’im' i дава́ли йánка, а по́тім пригла́джували ри́сум (Надсяння 318);

- 'на самому верху' (II CK) ↔ 'зверху на поверхні водойми, у верхньому прошарку рідини; на поверхні пристосування' (III CK) <бутu, плавати, ставати, варити>: Невели́ка рьіба, хрибе́т зелен'а́вий. Навіки зверх

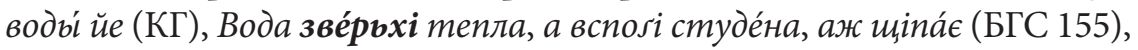
Розбо́вташ во́ду у фбля́шці та ста́не зви́рьха пі́на (КГ), I звервха мокре, i наспітку мокре (БГС 322), Шnар' гám ['чавунна кухонна плита'] на ки́хни стойі́m, зве́рха на ним йі́сти вар'а́m (ГГ 219);

- 'на самому низу' (II CK) ↔ 'знизу на поверхні землі; на дні водойми (посудини, пристосування)' (III СК) <бути, шукати>: Вода зве́рьхі тепла, а всполі студе́на, аж щъináє (БГС 155), То жо шука́ла, найшла́ аш усподу́ у скри́н' i (КСГГ); Поклала дитину у місие, де кінь їв сїно; 
як кінь переїв сіно, шукав у споду, форкав (Шух. IV 225).

- 'із самого верху' (II CK) ↔ 'із поверхні води' (III CK) <черпати>: Відгашене вугльи взьити з поверх води, покласти на бік, укрити платинков (Шух. V 245; ГС 154)

- 'із самого низу' (II CK) ↔ 'із дна водойми (посудини)’ (III CK) <набирати>: Зи спо́ду ни набира́й - там по́вно му́лу (Арк_С 188), Всі роди пампушниць (...) зі споду неполивані, зате заглиблення на пампухи поливані (Макс. 30) та ін.

\section{3. Лексикографічне моделювання прислівників}

Лексикографічне моделювання прислівників дає змогу не тільки систематизувати прислівники, утворені за однією моделлю, а й з'ясувати їх семантичну структуру відповідно до СК базових слів; ілюструючи їх функціювання прикладами, диференціювати прислівники та утворені від них прийменники, які зберігають безпосередній семантичний зв'язок із прислівниками, а також дійти висновків про те, що однотипність структури дериватів здебільшого зумовлює й ідентичну семантику.

Для дослідження системи дериватів визначальним є комплексне дослідження деривації, мотивацій та семантики похідних, адже ці аспекти є взаємозумовлюваними, вони доповнюють інформацію, а також дають змогу дійти достовірних висновків.

Усвідомлення того, що аналіз похідних лексем потребує глибшого дослідження, вивчення їх за іншими критеріями стало поштовхом до створення поліпроблемного словника, який комплексно відображатиме різні аспекти аналізу мовних одиниць.

Важливе значення має семантичне обмеження дериватів, що дає змогу не тільки виявити спільні компоненти значень слів, змоделювати на їх підставі узагальнені семантичні моделі для різних частин мови, що у подальшому можуть стати зразком лексикографічного представлення слів, а й виявити структурні мотиватори, які вказують на продуктивність моделей творення.

Простежити шляхи і способи творення слів, виявити семантичні зв'язки між дериватами, глибинні механізми формування та особливості семантики, що виявляє світогляд діалектоносіїв, дасть змогу Епідигматичний діалектний словник (далі - ЕДС), який передбачає комплексний підхід до представлення діалектних явищ - аналіз мотивації, деривації та семантики дериватів. Перевага ЕДС насамперед у його системності - передусім він відображає один із видів системних зв'язків, а також репрезентує лексику 
як цілість - системно, що є важливою умовою лексикографічного опрацювання діалектних явищ.

Мета ЕДС - структурно-семантичний аналіз СГ із вершинами верх, гора, низ, діл, спід у діалектах української мови, що дасть змогу вербалізувати семантичну опозицію «верх - низ» на підставі комплексного аналізу мотиваційних, дериваційних та семантичних особливостей дериватів.

Реєстрові слова уніфіковано в написанні - їх подано разом, за абеткою відповідно до ступенів деривації, наведено фонетичні варіанти (у дужках) та частину мови (зразок подання реєстрових слів див.: таблицю 1).

Таблиця 1

\begin{tabular}{|l|l|l|l|}
\hline I & вверху́ & $\left(\check{y}^{\prime} p^{\prime} \mid x y\right.$, в верxý, $y в е р x y ́, y$ верь $\left.x y\right)$ & $a d v$ \\
\hline $\begin{array}{l}\text { ступінь } \\
\text { деривації }\end{array}$ & $\begin{array}{l}\text { реєстрове } \\
\text { слово }\end{array}$ & фонетичні та орфографічні варіанти & $\begin{array}{l}\text { частина } \\
\text { мови }\end{array}$ \\
\hline
\end{tabular}

Структура словникової статті містить 3 блоки, які подано в таблиці:

- - дериваційний - вказано спосіб творення: для дериватів морфологічного способу подано у дужках афікс, відтак морфонологічні зміни в межах основи й на морфемному шві і словотвірну пару в напрямку від твірного до похідного; для неморфологічного способу - модель творення (для адвербіативів);

А - мотиваційний, який містить здебільшого 3 пункти: ЛМ - лексичний мотиватор і його значення; МЗ - мотиваційний зв'язок - напрямок мотивації, який фактично збігається 3 напрямком словотвірної похідності, дає змогу виявити закономірності номінації (наприклад: частина об’єкта > місце, місце > спосіб); у цьому пункті зазначено також перехід стилістично нейтрального слова у емоційно марковане (демінутив чи аугментатив); СМ - структурний мотиватор (якщо виявлено) - дериват із аналогійною семантичною і формальною структурою. Відзначу деяку умовність щодо цілісної структури СГ, яка, однак, не завжди зумовлена об'єктивними чинниками - не всі деривати виявлено та й чимало джерел ще очікують на опрацювання; зауважу, що для визначення лексичного мотиватора слова домінує семантика кореневої морфеми (базового слова), а для відповідних значень структурного мотиватора - семантика афіксальної морфеми;

- - семантичний - подано назву семантичного СК базового слова, відтак - в основній частині словникової статті - значення деривата, у трикутних дужках - дієслова, з якими поєднується реєстрове слово, зі статичною (бути, складати, рости, лежати, держати) 
чи динамічною (iтu, їхати, плавати, котитися, сипати, падати, ставити, притискати, застеляти, обмотувати) семантикою.

Ілюстративний матеріал подано після двокрапки; відтак - джерело фіксації.

Як приклад лексикографічного моделювання пропоную деривати, розташовані на трьох ступенях деривації (від базового слова верх):

I II III

\begin{tabular}{|c|c|c|c|c|}
\hline вверхх́ adv & $\rightarrow$ & вверхх́ $a d v^{1}$ & & \\
\hline & $\rightarrow$ & верики́ $a d v$ & $\rightarrow$ & вершку́ preap \\
\hline & $\rightarrow$ & ввершечки́ $a d v$ & & \\
\hline
\end{tabular}

I вверху́ (

- адвербіалізація (в + Loc)

А ЛМ: верх ‘верхня частина об’єкта'; МЗ: частина об’єкта > місце; СМ: внизу́, вcnodý

- 'верхня частина об'єкта'

1) 'у верхній частині рослини - дерева; у верховітті' <бути>: A в поли, в поли в три йивори, / Гей дай Боже!/ Тонкі, високі, в корінь глибокі, / В корінь глибокі, в верху листяті (Шух. IV 98)

2) 'у верхній частині елементів будівлі' <складати, збігатися>: На «коли́бу» ставлять (...) оструб, який імшать добре, аби у «хату» не віяло; верх оструба кладуть кізли так, аби вони усї збігли ся у верху до купи (Шух. II 174)

3) 'у верхній частині копиці' <складати>: Зберемо возів сімсот обозів,/ Ой повеземо на тихий Дунай,/ (...) Там їх <в'язанок пшениці> складемо в споду широко,/ В споду широко, в верху високо./ Чим завершимо? Сивим соколом! (Шух. IV 97)

4) 'на горі, на вершині гори; високо в горах; у гірській місцевості'<рости>: Навкруги́ був л’ic (...), а в верху́ на Та́рниии росли́ дес по од’н’i смере́и’i ma й же́репий (Піпаш 251); Розкинені гуиульскі хати (...) по «ке́черах» (горах

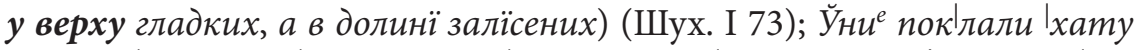

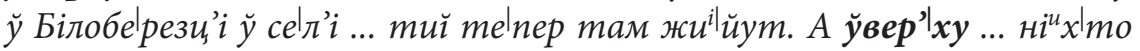

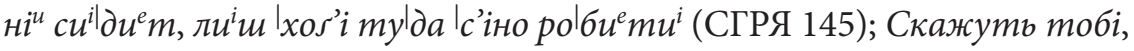
щзо яазда з котрим хочеш бесідувати, сидить "в верху», по итимеш до него трохи чи не иілу днину (Верхр_СЮ I)

5) 'у верхній течії річки' <бути> (Кміт 24; Он. I 87)

1 До уваги беремо також прислівники, утворені лексико-семантичним способом, пор.: II вверху́ $a d v$. 
II вверху́ (ввер'xý) adv

- лексико-семантичний

А ЛМ: вверху 'у верхній частині; вгорі, вверху'; МЗ: місце > спосіб; СМ: внизи́

- 'верхня частина об'єкта'

1) 'піднявши вгору <держати>: Ви́тко бу́ло, мене́ де́ржит на коне́и, на сами́й зад. А йа вже ни в'іде́ржував так довго держ'итти руку ввер'ху (Піпаш 257)

II ввершку́ ( $y$ верикy) adv

- суфіксація (-к-); х/ш; вверху $\rightarrow$ вверш-к(у)

А ЛМ: вверху 'у верхній частині об’єкта'; МЗ: нейтральне слово > демінутив; CM: -

- 'верхня частина об’єкта'

1) 'у верхній частині рослини - дерева; у верховітті' <бути, рости>: Зросли йі с'а брыва, гі туршкы ['смереки'] у вершку (КГ)

2) 'у верхній частині будівлі' <бути>: Кізли укривають дранииями або лубє, (...) лишаючи лиме у вершку «прозір» для проходу диму (Шух. II 174)

III ввершку́ ( $y$ вершкy) preap

- препозитивація

А ЛМ: ввершку (adv); СМ: -

- 'верхня частина об'єкта'

1) 'у верхній частині будівлі' <бути>: Дим з ватри іде «прозірем» у вершку колиби (Шух. II 175)

II ввершечку́ (в вершьичкý) $a d v$

- суфіксація (-ечк-); х/ш; вверху $\rightarrow$ вверш-ечк(у)

А ЛМ: вверху 'у верхній частині об'єкта'; МЗ: нейтральне слово > демінутив; СМ: -

- 'верхня частина об'єкта'

1) 'у верхній частині рослини' <бути>: Розкладають прядиво на мокрій лавици і скочують єго на кужівиї до купи у долинї грубше а в вершьички́ тонше (Шух. II 148). 
Аналізовані прислівники репрезентують такі способи словотворення, як: адвербіалізація, препозитивація, лексико-семантичний (утворення прислівника способу дії від локативного), суфіксація (для творення демінутивів ввершечќ́, уве́ршкý 'у верхній частині об'єкта'; пор.: літ. додолоньку, звершечку (СУМ-20 791, 1107).

Неусталеність написання прислівників разом, нарізно і навіть через дефіс (це виразно засвідчують діалектні джерела) значною мірою ускладнює процес аналізу й водночас підтверджує думку науковців про тривалість і незавершеність процесу адвербіалізації, про наявність перехідних одиниць, які умовно можемо зарахувати до прислівників. Це пов'язане, зокрема, із неможливістю диференціювати прислівник і прийменниково-іменникову конструкцію, які мають те саме семантичне навантаження, наприклад: Навкруги́ був л’ic (...), а в верху́ ['на вершині гори'] на Та́рниนи росли́ дес по од'н'i смере́u'i та й же́репий (Піпаш 251), Зросли йі с'а брыва, zi туршкы ['смереки'] у вершку ['на верхівці дерева'] (КГ), Прядиво (...) у долинї грубще а в вершьичку́ ['на верхівці дерева'] тонше; Кізли укривають дранииями або лубє, (...) тишаючи тише у верику ['у верхній частині будівлі'] «прозір» для проходу диму; Дим з ватри іде «прозірем» у верику колиби (Шух. II 148, 174, 175).

Аналіз корпусу прислівників у говірках української мови засвідчив важливість повноти та коректності подачі значень у діалектних словниках, уникнення тлумачень поза контекстом, адже мовні ілюстрації, мікро- та макроконтексти $є$ визначальними для окреслення семантики слів, через недостатність яких і неповноту цитованого матеріалу визначити значення слова неможливо (пор., наприклад: Не ца́т'і у гор'í (Он. II 349); Та йа го там ўнизу́ ўз'е́у (КСГГ)) та ін.

Зафіксовано значну кількість прикладів, у яких реалізується обидва «полюси» семантичні опозиції в одному мікроконтексті, а саме: вверху - вдолині (по «кєчерах» (горах у верху гладких, а в долинї залїсних)); вверху - всподу (в споду широко, в верху високо); ввершечку́ - вдолині (прядиво (...) у долинї грубше а в вершвичку́ тонще); вгорі - вдолині (колиска має вгорі паку (...) і вдолині - кружки; вдолині стіг є шириий, вгорі вужчий; штучна гать мірить у горі $80 \mathrm{~m}$. а в долинї 20 m.); горою вдолині (має вдолині й середині по 2 обручі, горою один); горою - всподу (у споду вона плоска, а горою круглава); зверхі - всподі (вода зве́рьхі тепла, а всполі студе́на); наверсі - всподі (все всподі - не наверсі); наверха всподі (все всподі - не наверха); наверху - всподу (боки́ ў споду́, а гир'ки наве́рху) тощо.

Інколи засвідчено приклади, які пов'язані тільки з «в ерхом» (ууго́ру 'дибом, стійма', зве́рху, пове́рх 'через край об’єкта', зве́рху, пове́рха 'повер- 
хово; неглибоко', наве́рх, пове́рх 'поверх, на випуск, не заправляючи (сорочки, штанів)', горі́, зве́рху, наве́рх ‘близько, поруч, поряд’), або тільки 3 «низом» (ўдоли́ну 'повільно <грати>', до́лом 'низько, грубо <звучати>);

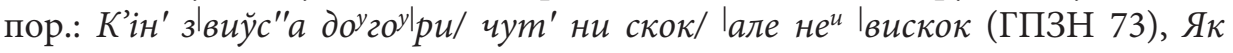
окріп у горшку іде по верх крис, заки закипить, то буде слота (Шух. IV 6), То й на о́ко ви́тко, як кров жби́хає, бо жи́ли зве́рху (БГС 110), Вбрав соро́чку по́верес штані́ (Негрич 137), Шо бо́рше стра́битиси ['буде потрібно'], клади́ наве́рхв (БГС 525); Як залі́ чолові́к, то сиділа-м горі́ ним півро́ку, по́ки бінний ни вмер (Матіїв 104); Ой заграйте, музичуки, вдолину, вдолину, та най собі вигуляю свою білявину (КСГГ); Як шумить потік, то не добре, i тогди не добре, як по ви́соку вітер віє або гримить, а як долом по тихо віє, то добре [Шух. I 89 (Гуц.)].

Прислівники, що репрезентують IV CK - «верхи (на коні)», також апелюють тільки до «верху»: Всі йі́хали зве́рхе на ко́н'ах (КСГГ), Цияан, мала дитина, а юж зна ити верхы на кони (Пиртей 147), 3 далеких верхів сходять «верхівиї», одні «пішє» другі «верхо́м» (на кони), плаїчками, плаями, сутками, вулииями на дороги (Шух. I 77).

Аналіз дериватів, засвідчених у діалектологічних джерелах, також дав змогу виявити специфічні діалектні фонетичні особливості на різних рівнях мови, що відображають специфіку мовлення носіїв говорів.

\section{Бібліографія}

\section{Джерела}

Арк_C - Григорій Аркушин, Словник західнополіських говірок, Луцьк 2016.

БГТ - Буковинські говірки: хрестоматія діалектних текстів, ред. Ніна Гуйванюк, Чернівці 2006.

ГС - Наталія Хобзей, Тетяна Ястремська, Оксана Сімович, Ганна Дидик-Меуш, Гуцульські світи: Лексикон, Львів 2013.

БГС - Словник буковинських говірок, ред. Ніна Гуйванюк, Чернівці 2005.

Верхр_СЮ - Іван Верхратский, Знадоби до словаря южноруского, Львів 1877.

ГГ - Гуцульські говірки: Короткий словник, ред. Ярослава Закревська, Львів 1997. ГПЗН - Говірки південно-західного наріччя української мови : збірник текстів, ред. Наталія Глібчук, Львів 2000.

КГ - Картотека Словника говірок Закарпатської обл. Миколи Грицака [зберігається в Інституті української мови НАН України, Київ].

Кміт - Юрій Кміт, Словник бойківського говору, «Літопис Бойківщини», т. III-XI, Самбір 1934-1939.

КСГГ - Картотека Словника гуцульських говірок [зберігається в Інституті українознавства ім. І. Крип’якевича НАН України, Львів]. 
Макс. - Іван Максимчук, Домашня й кухонна посудина в Старім Самборі, «Літопис Бойківщини», ч. V, Самбір 1935.

Матіїв - Микола Матіїв, Словник говірок Центральної Бойківщини, КиївСімферополь 2013.

Мосора - Михайло Мосора, Словар гуцульський зібраний Михайлом Мосорою /

Рукопис, 1885-1896 [зберігається в архіві ім. І. Франка у Києві. - №3/100].

Надсяння - Надсяння: Традиційна культура і побут (етнолінгвістичні матеріали),

ред. Михайло Глушко, Леся Хомчак, Львів 2017.

Негрич - Микола Негрич, Скарби гуцульського говору: Березови́, Львів 2008.

Он. - Михайло Онишкевич, Словник бойківських говірок, т. 1-2, Київ 1984.

Пиртей - Петро Пиртей, Словник лемківської говірки, Івано-Франківськ 1986.

Піпаш - Юрій Піпаш , Борис Галас, Матеріали до словника гуцульських говірок

(Косівська Поляна і Росішка Рахівського р-ну Закарпатської області), Ужгород 2005.

СГРЯ - Марія Астаф’єва, Ганна Воронич, Словник гуцульських говірок Річки та Яворова, кн. 1, Івано-Франківськ 2014.

СУМ-20 - Тлумачний словник української мови: в 20-ти томах (електронна версія

Українського мовно-інформаційного фонду НАН України), http://test.ulif.org.ua [доступ 12.11.2018].

УЗГТ -Українські закарпатські говірки. Тексти, ред. Ольга Миголинець, Ольга Пискач, Ужгород 2004.

Шух. - Шухевич Володимир, Гуцульщина, ч. I-V, Львів 1899-1908.

\section{Література}

Апресян Юрий, 1997, Дейксис в лексике и грамматике и наивная модель мира, «Семиотика и информатика», вып. 35, Москва, с. 272-298.

Гриценко Павло, 1984, Моделювання системи діалектної лексики, Київ.

Гриценко Павло,1990, Ареальне варіювання лексики, Київ.

Грищенко Арнольд (ред.), 1997, Сучасна українська літературна мова, Київ. Німчук Василь (ред.), 1978, Історія української мови. Морфологія, Київ.

\section{Streszczenie}

W artykule przebadano przysłówki lokatywne, które reprezentują opozycję semantyczną góra - dół. Przedstawiono nowe podejście analizy systemu derywatów w odniesieniu do epidygmatycznego słownika dialektalnego. Interpretacja wybranych przysłówków została oparte na materiale gwar ukraińskich. 